The submitted manuscript has been authored
by a contractor of the U.S. Government
under contract No. W-31-109-ENG-38.
Accordingly, the U. S. Government retains a
nonexclusive, royalty-free license to publish
or reproduce the published form of this
contribution, or allow others to do so, for
U.S. Government purposes.

Y. Goharil), M.

ITER Breeding Blanket Design

\title{
ANL/ET/CP- -90987
}

D. Lousteau(1), P. Lorenzetto(3), S. Majumdar(2), R. Mattas(2), K. Mohri(1),

R. Raffray(1), Y. Strebkov(5), H. Takatsu(4), E. Zolti(1)

(1) ITER Joint Central Team, Garching, Garching Co-center, Boltzmannstrasse 2, D-85748 Garching, Germing
(2) Fusion Power Program, Argonne National Laboratory, 9700 S. Cass Ave., Argonee IL 60439, USA

(3) NET Team, Max-Planck-Institut für Plasmaphysik, Boltzmannstrasse 2, D-85748 Garching, Germany

(4) Plasma Engineering Laboratory, Japan Atomic Energy Research Institute, Naka, Japan

(5) Research and Development Institute of Power Engineering, Moscow 101000, Russia

\section{ABSTRACT}

A breeding blanket design has been developed for ITER to provide the necessary tritium fuel to achieve the technical objectives of the Enhanced Performance Phase. It uses a ceramic breeder and water coolant for compatibility with the ITER machine design of the Basic Performance Phase. Lithium zirconate and lithium oxide are the selected ceramic breeders based on the current data base. Enriched lithium and beryllium neutron multiplier are used for both breeders. Both forms of beryllium material, blocks and pebbles are used at different blanket locations based on thermo-mechanical considerations and beryllium thickness requirements. Type $316 \mathrm{LN}$ austenitic steel is used as structural material similar to the shielding blanket. Design issues and required R\&D data are identified during the development of the design.

\section{INTRODUCTION}

A ceramic-breeder water-cooled blanket design has been developed for ITER to replace the shielding blanket of the Basic Performance Phase (BPP). It provides the required tritium for ITER operation during the Enhanced Performance Phase (EPP) and it also performs all the functions of the shielding blanket. It is based on a modular design concept similar to the shielding blanket modules [1]. These modules have been developed to be compatible with the shielding blanket where the physical interfaces, the maintenance procedure, and the water coolant parameters are the same for both blankets. The current design status of the breeding blanket is described in this paper.

\section{BREEDING BLANKET DESIGN DESCRIPTION}

In order to satisfy the ITER design requirements, the breeding blanket has to have the following main features: a) a modular design approach for replacement and maintenance reasons, b) a compact design to permit the use of sufficient shielding materials at the back of the module, c) a high local tritium breeding ratio to produce the necessary tritium to achieve a neutron fluence in the range of 1 to $3 \mathrm{MW} . \mathrm{a} / \mathrm{m}^{2}$. Based on design analyses and previous design experience $[2,3]$, these requirements lead to the selection of the layered design.

\section{Breeder material}

Lithium zirconate $\left(\mathrm{Li}_{2} \mathrm{ZrO}_{3}\right)$ and lithium oxide $\left(\mathrm{Li}_{2} \mathrm{O}\right)$ breeders have been selected based on the current data base of the different solid breeder materials. Tritium breeding capability, ease and reliability of tritium recovery, thermal transport properties, fabrication experience, and thermal, chemical, and irradiation stability are the main. factors in this selection. $\mathrm{Li}_{2} \mathrm{O}$ has the advantages of a relatively high lithium atom density for tritium breeding, good thermal conductivity for reduced thermal stresses, low tritium inventory at temperatures above the critical temperature for precipitating out LiOT as a separate phase, and low activation. However it is very sensitive to the moisture during fabrication and operation. It requires tighter controls on both as-fabricated and purge-flow moisture levels in order to exhibit acceptable tritium inventory. $\mathrm{Li}_{2} \mathrm{ZrO}_{3}$ has the advantages of less sensitivity to moisture, lower tritium inventory at low temperatures, excellent chemical, microstructural and irradiation stability, and better material compatibility with the structural materials. Zirconium activation, lower lithium atom density for tritium breeding, and lower thermal conductivity relative to the $\mathrm{Li}_{2} \mathrm{O}$ are the main disadvantages of the $\mathrm{Li}_{2} \mathrm{ZrO}_{3}$ breeder material. Pellets and pebbles are under consideration for the breeder material form. For $\mathrm{Li}_{2} \mathrm{ZrO}_{3}$ breeder, the thermal conductivity values of both forms are very close, which favor the use of pebbles to reduce the thermal stresses in the breeder material. Also, it does facilitate the fabrication of the breeder zones. In the case of $\mathrm{Li}_{2} \mathrm{O}$ breeder, the difference in thermal conductivity of both forms is much larger. Detailed design analyses and experimental data base will be used for the final material and form selection.

The need for high local tritium breeding ratio dictates the use of beryllium neutron multiplier and high lithium- 6 enrichment. The use of high lithium- 6 enrichment reduces the breeder volume required in the blanket and consequently the total tritium inventory. Also, it reduces the temperature variation in the solid breeder material that increases the blanket capability to accommodate power excursion.

\section{neutron multiplier material}

Both forms of beryllium material. blocks and pebbles are used in the breeding blanket. Beryllium blocks are used in the front section of the blanket for several reasons. Beryllium blocks have good thermal conductivity value relative to the pebbles that accommodates the high values of nuclear heating and permits the use of the required beryllium thickness for neutron multiplication without having high operating 


\section{DISCLAIMER}

Portions of this document may be illegible in electronic image products. Images are produced from the best available original document. 


\section{DISCLAIMER}

This report was prepared as an account of work sponsored by an agency of the United States Government. Neither the United States Government nor any agency thereof, nor any of their employees, makes any warranty, express or implied, or assumes any legal liability or responsibility for the accuracy, completeness, or usefulness of any information, apparatus, product, or process disclosed, or represents that its use would not infringe privately owned rights. Reference herein to any specific commercial product, process, or service by trade name, trademark, manufacturer, or otherwise does not necessarily constitute or imply its endorsement, recommendation, or favoring by the United States Government or any agency thereof. The views and opinions of authors expressed herein do not necessarily state or reflect those of the United States Government or any agency thereof. 
temperature. Also, the low porosity of the sintered beryllium blocks improves the shielding performance and the safety characteristics of the breeding blanket. Beryllium pebbles are used at the rear section of the breeding blanket module for two reasons. The nuclear heating is lower than the front section, which permits the use of low thermal conductivity material. The required beryllium thickness for neutron multiplication is less, which favor the pebbles for simple fabrication procedure.

\section{Structural Material}

Type $316 \mathrm{LN}$ austenitic steel in the solution annealed condition has been selected as the structure material for the breeding blanket similar to the shielding blanket. Good fabricability, extensive data base, and nuclear experience are the main reasons for this selection. Low temperature (100 to $150^{\circ} \mathrm{C}$ ) water coolant is used to enhance the operating performance of the $316 \mathrm{LN}$ austenitic steel. Structure steel temperature limits are $<400{ }^{\circ} \mathrm{C}$ because of radiation induced swelling and $<200{ }^{\circ} \mathrm{C}$ at the water interfaces because of aqueous stress corrosion consideration.

\section{Blanket Geometry}

The inboard blanket modules have two breeder zones embedded in beryllium with three coolant panels used to cool the module. The first wall has the first coolant panel to remove the surface heat flux and the nuclear heating from the front section of the breeding blanket module. The second panel is located between the two breeder zones separated by beryllium material. The last coolant panel is located at the back section of the blanket to remove the heat from the back section of the breeding blanket and the front section of the shielding material. The outboard blanket module is similar to the inboard except it has three breeder zones to enhance the local tritium breeding ratio. This is pøssible because of less geometrical constrain on the outboard section relative to the inboard. Figs. 1, 2 and 3 show the blanket design for the inboard and outboard sections featuring the same support method of the shielding blanket modules to the back plate.

The breeder zone consists of $10 \mathrm{~mm}$ breeder material $\left(\mathrm{Li}_{2} \mathrm{ZrO}_{3}\right.$ or $\mathrm{Li}_{2} \mathrm{O}$ ) with a $1 \mathrm{~mm}$ thick $316 \mathrm{LN}$ stainless steel clad to form a panel. These panels are continuous inside the blanket module and have built in poloidal helium purge lines on the sides. Helium purge gas flows through the manifold, then toroidally across the breeder panel through the pebbles or grooves in the pellets, and finally back out through the return manifold. This purge gas carries the produced tritium from the breeder material.

The first wall is a $316 \mathrm{LN}$ stainless steel panel with built-in rectangular coolant channels with a $14 \mathrm{~mm}$ total thickness. However, the thermal stress analysis shows that the total first wall thickness should be in the range of 12 to $13 \mathrm{~mm}$. A 5 $\mathrm{mm}$ beryllium is used as coating material to protect the first wall from the plasma interaction. The coolant panels inside the blanket module are similar to the first wall with $9 \mathrm{~mm}$ total thickness. Material aspects, fabrication considerations, and design analyses (neutronics, heat transfer, tritium recovery, and stress analyses) were performed to define the blanket configuration.

\section{TRITIUM BREEDING REQUIREMENTS}

ITER schedule calls for DT operation to start in the year 2009 , the expected tritium resources available from Ontario Hydro at this time are $-22 \mathrm{~kg}$ and $1.5 \mathrm{~kg} / \mathrm{a}$. The ITER operating scenario is used to define the tritium requirements based on $1500 \mathrm{MW}$ of fusion power. The BPP has 10 years. with a $0.3 \mathrm{MW} . \mathrm{a} / \mathrm{m}^{2}$ integrated neutron fluence over the last 7.5 years without breeding capability. The tritium burn rate in this seven and half years is $3.36 \mathrm{~kg} / \mathrm{a}$ assuming constant availability. Also, the EPP has 10 years with 1 to 3 $\mathrm{MW} . \mathrm{a} / \mathrm{m} 2$ fluence range. Assuming an availability range of 7 to $27 \%$ for the EPP, which results in 0.7 to 2.7 full power years. The required tritium burn rate is 5.9 to $22.7 \mathrm{~kg} / \mathrm{a}$ for this range of fluence goal. Table I gives the required external tritium supply rate and the integrated tritium consumption for the two phases of ITER as a function of the net tritium breeding ratio of the blanket and the same fluence range. The total steady state tritium inventory in the plasma facing material, fueling and exhaust systems, and other ITER reactor components is assumed to be about $5 \mathrm{~kg}$.

The above external tritium will be adequate for the BPP if the total steady state tritium inventory can be reduced to $3.0 \mathrm{~kg}$. In the EPP, a tritium breeding blanket is essential to achieve the lowest value of the fluence goal of $1 \mathrm{MW} . \mathrm{a} / \mathrm{m}^{2}$. Table II gives the minimum net tritium breeding ratio required to achieve the fluence goal values of 1 to $3 \mathrm{MW} . \mathrm{a} / \mathrm{m} 2$ based on the above expected tritium resources.

Table 1

Required External Tritium Supply Rate as a Function of Fluence Goal and Net Tritium Breeding Ratio

\begin{tabular}{|cccccccc|}
\hline $\begin{array}{c}\text { Total } \\
\text { Neutron } \\
\text { Fluence }\end{array}$ & \multicolumn{2}{c}{$1.0 \mathrm{MW} . \mathrm{a} / \mathrm{m}^{2}$} & \multicolumn{2}{c|}{$2.0 \mathrm{MW} . \mathrm{a} / \mathrm{m}^{2}$} & $3.0 \mathrm{MW} . \mathrm{a} / \mathrm{m}^{2}$ \\
$\begin{array}{c}\text { Net } \\
\text { Tritium } \\
\text { Breeding } \\
\text { Ratio }\end{array}$ & $\begin{array}{c}\text { Supply } \\
\text { Rate } \\
(\mathrm{kg} / \mathrm{y})\end{array}$ & $\begin{array}{c}\text { Total } \\
\text { External } \\
\text { Tritium } \\
(\mathrm{kg})\end{array}$ & $\begin{array}{c}\text { Supply } \\
\text { Rate } \\
(\mathrm{kg} / \mathrm{y})\end{array}$ & $\begin{array}{c}\text { Total } \\
\text { External } \\
\text { Tritium } \\
(\mathrm{kg})\end{array}$ & $\begin{array}{c}\text { Supply } \\
\text { Rate } \\
-(\mathrm{kg} / \mathrm{y})\end{array}$ & $\begin{array}{c}\text { Total } \\
\text { External } \\
\text { Tritium } \\
(\mathrm{kg})\end{array}$ \\
0.0 & 4.8 & 106 & 10.6 & 207 & 16.3 & 308 \\
0.5 & 2.8 & 71 & 5.7 & 121 & 8.6 & 172 \\
0.6 & 2.4 & 64 & 4.7 & 104 & 7.0 & 144 \\
0.7 & 2.0 & 57 & 3.7 & 87 & 5.4 & 117 \\
0.8 & 1.6 & 49 & 2.7 & 70 & 3.9 & 90 \\
0.9 & 1.2 & 42 & 1.7 & 53 & 2.3 & 63 \\
\hline
\end{tabular}

\section{NET TRITIUM BREEDING RATIO}

The net tritium breeding ratio is assessed for the ITER configuration where the breeding blanket geometrical coverage, neutron wall loading distribution, and local tritium breeding ratio are included in the assessment. The neutron wall loading distribution is used with the poloidal configuration of the machine to calculate the neutron coverage of the different components in the plasma chamber. The results show the neutron coverage of the breeding blanket modules is about $71 \%$ of the total DT neutrons excluding the mid-plane ports, limiter, and bafiles as shown in Table III. 


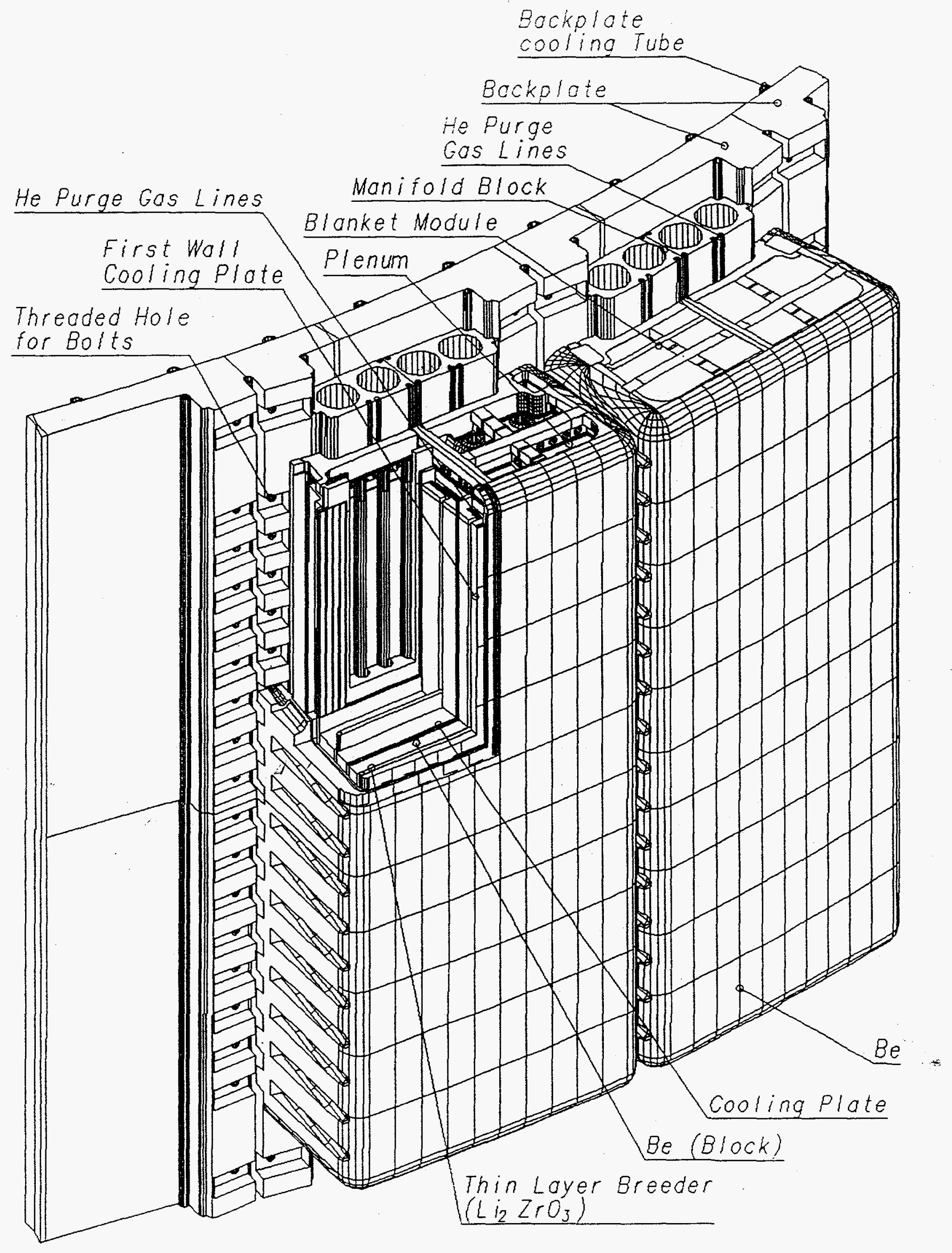

Fig. 1 Inboard Breeding Blanket Modules 


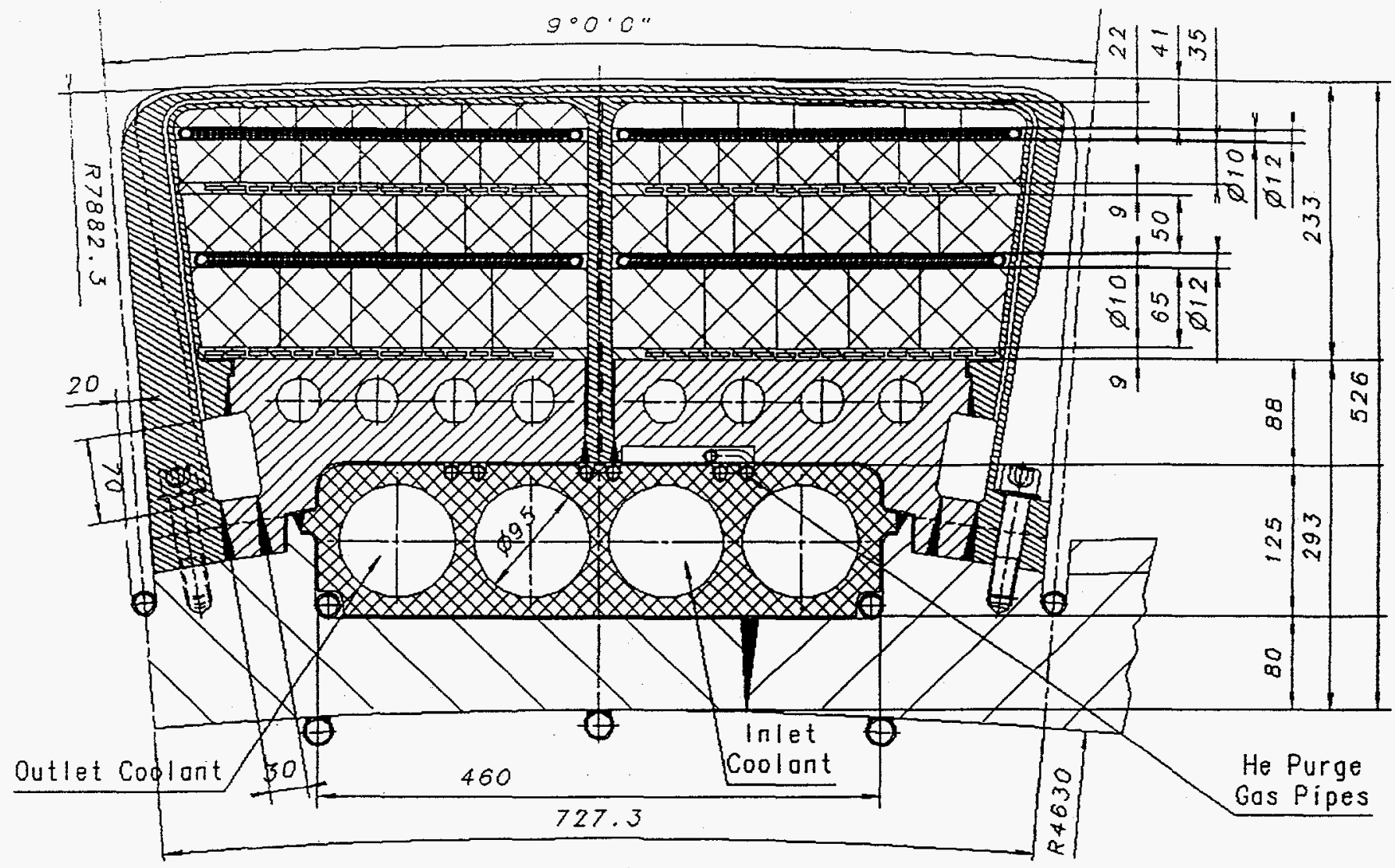

Fig. 2 Inboard Breeding Blanket Cross Section

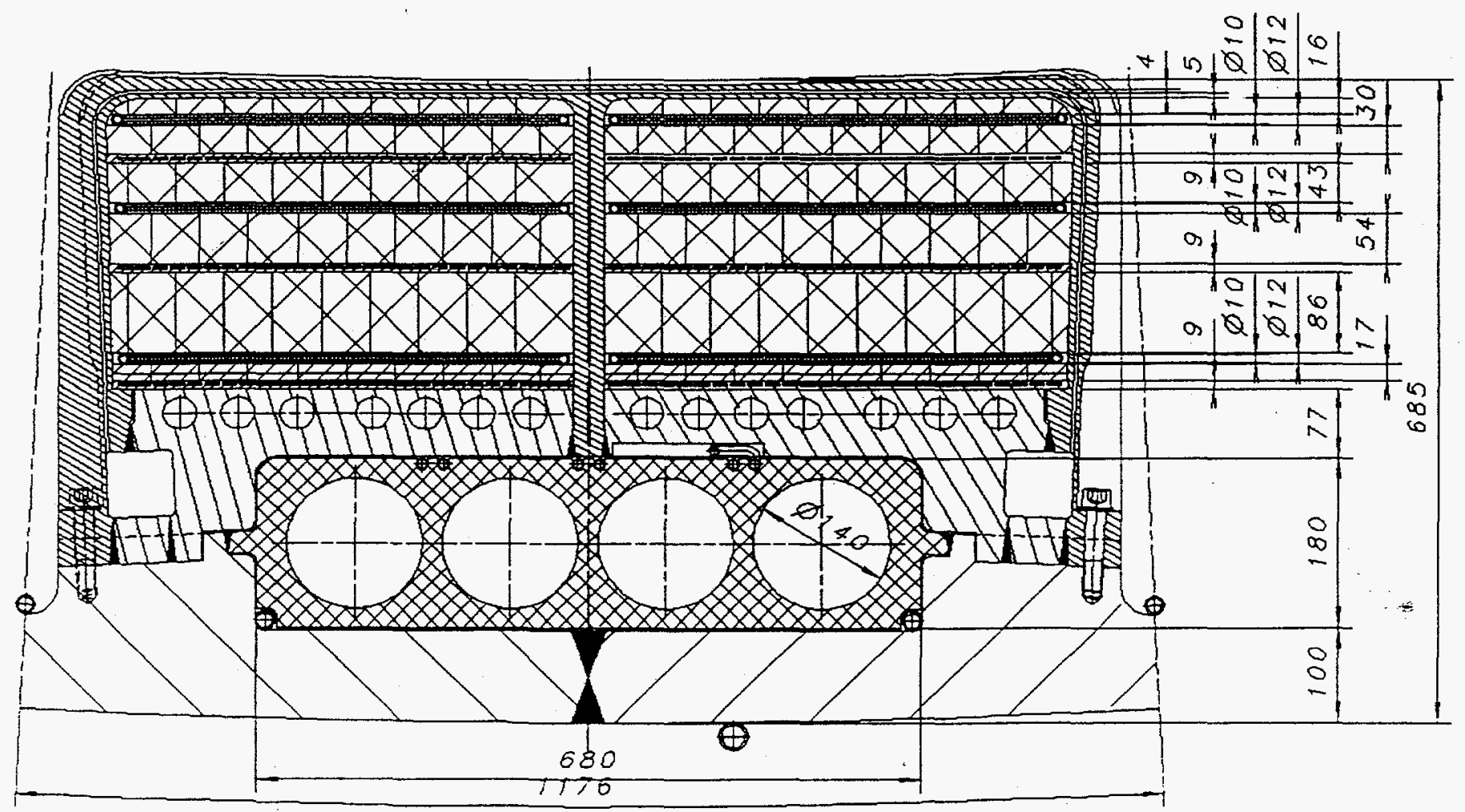

Fig. 3 Outboard Breeding Blanket Cross Section 
Table II

Net Tritium Breeding Ratio Required for Different Total Neutron Fluence Values

$$
\begin{aligned}
& \text { Total Neutron Fluence } \\
& \text { (MW.a/m } \mathrm{m}^{2} \text { ) } \\
& \begin{array}{ll}
1.0 & 0.818 \\
2.0 & 0.925 \\
3.0 & 0.953
\end{array} \\
& \begin{array}{ll}
3.0 & 0.953
\end{array}
\end{aligned}
$$

The net tritium breeding is calculated using the radial build given in Table IV. The radial thicknesses of the breeding blanket are $23.4 \mathrm{~cm}$ for the inboard and $32.8 \mathrm{~cm}$ for the outboard. The calculated net tritium breeding ratio is 0.88 excluding the use of the limiter, baffles, and equatorial ports. The use of a breeding section behind the high heat flux sections of the limiter and baffles increases the net tritium breeding ratio above 1.0 . This breeding capability permits ITER to operate for a fluence goal in the range of 1 to 3 MW. $a / \mathrm{m}^{2}$ based on the results shown in Table II. In this analysis, it is assumed that the gap between modules and side walls account for a $6 \%$ loss of the neutron coverage of the breeding blanket. Assuming the same loading conditions of the shielding blanket, the required first wall stiffeners will reduce this net tritium breeding ratio by less than $5 \%$. The losses in the local tritium breeding ratio are 0.15 and $0.21 / \mathrm{cm}$ of steel and water in the first wall, respectively. These results give a strong motivation to reduce the thickness of the first wall and to use local stiffeners to accommodate the different design loads. Also, the analyses show that about $1.0 \mathrm{~cm}$ thick breeder zone provides an acceptable thickness for tritium production and maximum breeder temperature.

Table III

DT Neutron Coverage

\begin{tabular}{|cccc|}
\hline Component & \multicolumn{2}{c}{ Geometrical/Coverage } & $\begin{array}{c}\text { DT Neutron } \\
\text { Coverage } \\
\%\end{array}$ \\
Area $\left(\mathrm{m}^{2}\right)$ & $\%$ & \\
Inboard Blanket & 294 & 22.2 & 15.9 \\
Outboard Blanket & 618 & 46.6 & 55.0 \\
Equatorial Ports & 46 & 3.5 & 4.6 \\
Inboard Baffle & 59 & 4.5 & 2.5 \\
Outboard Baffle & 65 & 4.9 & 3.2 \\
Limiter & 155 & 11.7 & 14.2 \\
Divertor & 88 & 6.6 & 4.6 \\
\hline
\end{tabular}

Also, the effect of the total beryllium thickness on the local tritium breeding is shown in Fig. 4 where the thickness of the first wall, the coolant panels, and the breeder zones are kept constant. As the beryllium content in the blanket increases, the neutron multiplication, the local tritium breeding ratio, and the parasitic neutron absorption increases. Also, the average neutron energy is decreased due to the neutron scattering and multiplication reactions with the beryllium material. As the average neutron energy decreases below the threshold for neutron multiplication, the increase of the parasitic neutron absorption results in lower tritium production. The local tritium breeding ratio peaks at about 50 $\mathrm{cm}$ total blanket thickness as shown in Fig. 4. About $30 \mathrm{~cm}$ total blanket thickness is adequate to reach very close to the peak value of the tritium breeding for such type of design

\begin{tabular}{|c|c|c|c|}
\hline \multirow{3}{*}{$\begin{array}{c}\text { Region by } \\
\text { Function } \\
\text { Tile } \\
\text { First Wall }\end{array}$} & Materials & \multicolumn{2}{|c|}{$\begin{array}{l}\text { Zone Thickness-cm (porosity) } \\
\text { Inboard }\end{array}$} \\
\hline & \multirow{24}{*}{ 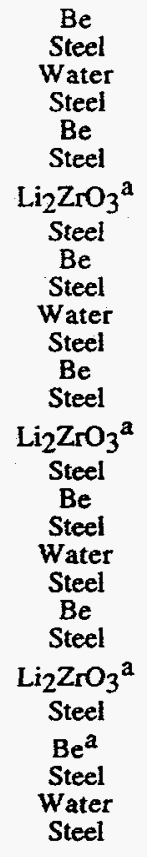 } & 0.5 & 0.5 \\
\hline & & 0.5 & 0.5 \\
\hline & & 0.4 & 0.4 \\
\hline \multirow{4}{*}{$\begin{array}{l}\text { Multiplier } \\
\text { Breeder }\end{array}$} & & 0.5 & 0.5 \\
\hline & & $2.0(0.15)$ & $1.6(0.15)$ \\
\hline & & 0.1 & 0.1 \\
\hline & & $\begin{array}{c}1.0(0.3) \\
0.1\end{array}$ & $\begin{array}{c}1.0(0.3) \\
0.1\end{array}$ \\
\hline \multirow{3}{*}{$\begin{array}{l}\text { Multiplier } \\
\text { Coolant }\end{array}$} & & $3.5(0.15)$ & $3.0(0.15)$ \\
\hline & & 0.3 & 0.3 \\
\hline & & $\begin{array}{l}0.3 \\
0.3\end{array}$ & $\begin{array}{l}0.3 \\
0.3\end{array}$ \\
\hline \multirow{3}{*}{$\begin{array}{l}\text { Multiplier } \\
\text { Breeder }\end{array}$} & & $5.0(0.2)$ & $4.3(0.15)$ \\
\hline & & 0.1 & \\
\hline & & $\begin{array}{c}1.0(0.3) \\
0.1\end{array}$ & $\begin{array}{l}1.0(0.3) \\
0.1\end{array}$ \\
\hline \multirow{4}{*}{$\begin{array}{l}\text { Multiplier } \\
\text { Coolant }\end{array}$} & & $6.8(0.2)$ & $5.4(0.15)$ \\
\hline & & 0.3 & 0.3 \\
\hline & & 0.3 & 0.3 \\
\hline & & 0.3 & 0.3 \\
\hline \multirow{3}{*}{$\begin{array}{l}\text { Multiplier } \\
\text { Breeder }\end{array}$} & & - & $8.6(0.15)$ \\
\hline & & - & 0.1 \\
\hline & & 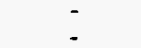 & $\begin{array}{c}1.0(0.3) \\
0.1\end{array}$ \\
\hline \multirow{4}{*}{$\begin{array}{c}\text { Multiplier } \\
\text { Coolant }\end{array}$} & & . & $1.7(0.3)$ \\
\hline & & - & 0.3 \\
\hline & & $=$ & 0.3 \\
\hline & & - & 0.3 \\
\hline \multicolumn{2}{|c|}{ Total radial thickness } & 23.4 & 32.8 \\
\hline \multicolumn{2}{|c|}{ Local Tritium breeding Ratio } & 1.15 & 1.38 \\
\hline
\end{tabular}
without using excessive amount of beryllium.

Table IV

Radial Build of the Breeding Blanket Section

a-Binary pebble bed

\section{THERMAL ANALYSIS}

The thermal analysis of the breeding blanket was performed to determine the change in the heat transport system relative to the shielding blanket requirements. The neutron energy multiplication factor for the breeding blanket is 1.60 compared to 1.56 for the shielding blanket. The corresponding total thermal power is $2072 \mathrm{MW}$, including $80 \%$ of the alpha particle's energy to the first wall surface and $4.6 \%$ of the DT neutron to the divertor zone. The corresponding thermal power for the shielding blanket is $2026 \mathrm{MW}$. The power difference between the two blankets is about $2 \%$ that can be accommodated by the heat transport system.

A two-dimensional model was used to calculate the temperature distribution in the different components of the breeding blanket. The radial distributions of the nuclear heating shown in Figures 5 and 6 were used to perform the heat transfer and the thermal hydraulics. Table $\mathrm{V}$ gives the extreme temperatures of the different blanket materials for 100 ${ }^{\circ} \mathrm{C}$ inlet water coolant temperature. The maximum beryllium temperature and temperature gradient are kept less than 300 and $23{ }^{\circ} \mathrm{C}$, respectively. These values significantly reduce radiation induced swelling and thermal stress of the beryllium material. 


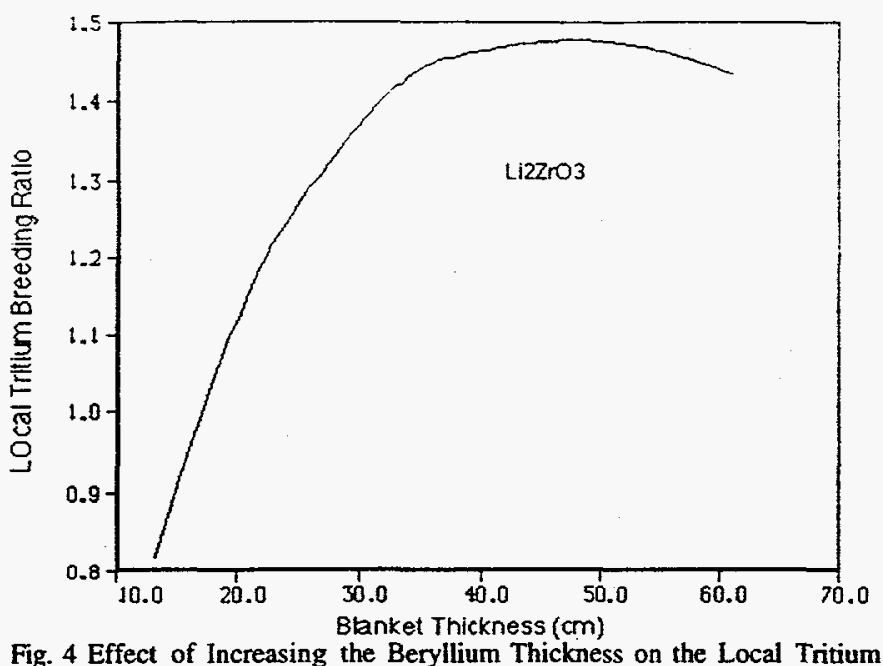

Table $\mathrm{V}$

Extreme Temperature of the Breeder and Multiplier materials for $\mathrm{Li}_{2} \mathrm{ZrO}_{3}$ Breeding Blanket with $1 \mathrm{MW} / \mathrm{m}^{2}$ Neutron wall Loading

\begin{tabular}{|cccc|}
\hline $\begin{array}{c}\text { Region by } \\
\text { Function }\end{array}$ & Materials & \multicolumn{2}{c|}{$\begin{array}{c}\text { Min.- Max. Temperature, }{ }^{\circ} \mathrm{C} \\
\text { Inboard }\end{array}$} \\
& & & Outboard \\
Multiplier & $\mathrm{Be}$ & $221-255$ & $244-281$ \\
Breeder & $\mathrm{Li}_{2} \mathrm{ZrO}_{3}$ & $321-558$ & $365-699$ \\
Multiplier & $\mathrm{Be}$ & $193-254$ & $213-281$ \\
Multiplier & $\mathrm{Be}$ & $179-245$ & $201-280$ \\
Breeder & $\mathrm{Li}_{2} \mathrm{ZrO}$ & $291-451$ & $346-612$ \\
Multiplier & $\mathrm{Be}$ & $166-246$ & $188-281$ \\
Multiplier & $\mathrm{Be}$ & - & $163-246$ \\
Breeder & $\mathrm{Li}_{2} \mathrm{ZrO}$ & - & $272-386$ \\
Multiplier & $\mathrm{Be}$ & - & $121-248$ \\
& & &
\end{tabular}

Fig. 4 Effect of Increasing the Beryllium Thickness on the Local Tritium Breeding Ratio

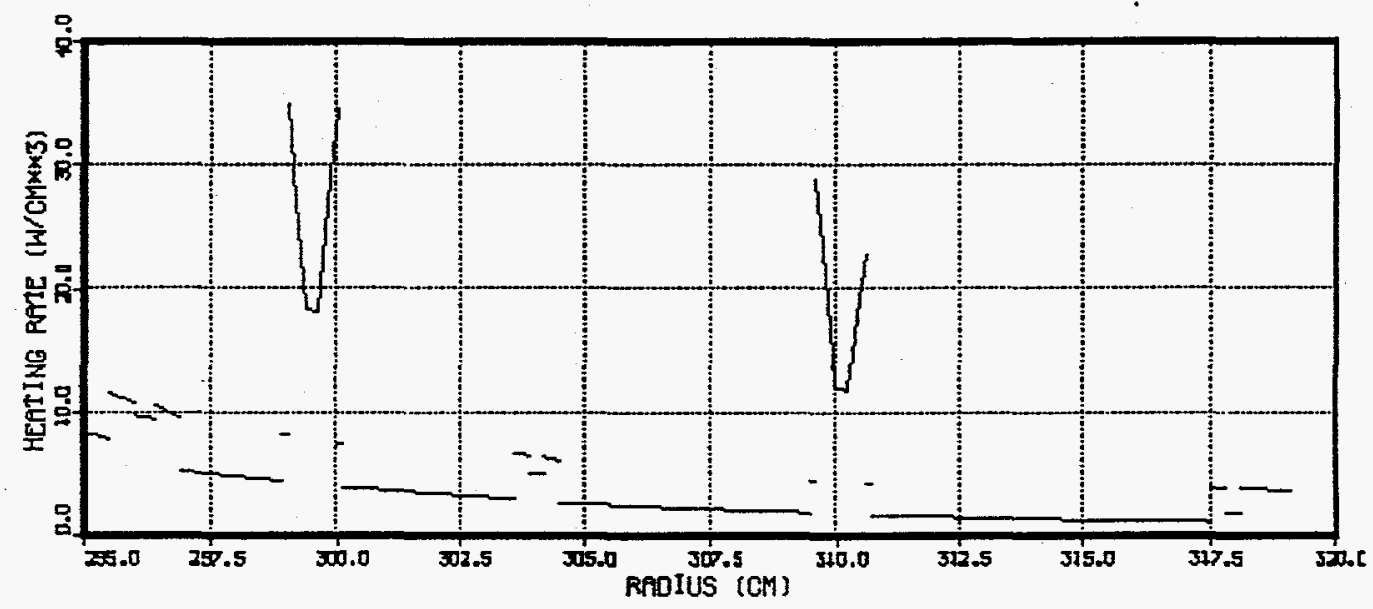

Fig. 5 Inboard Radial Distribution of the Total Nuclear Heating

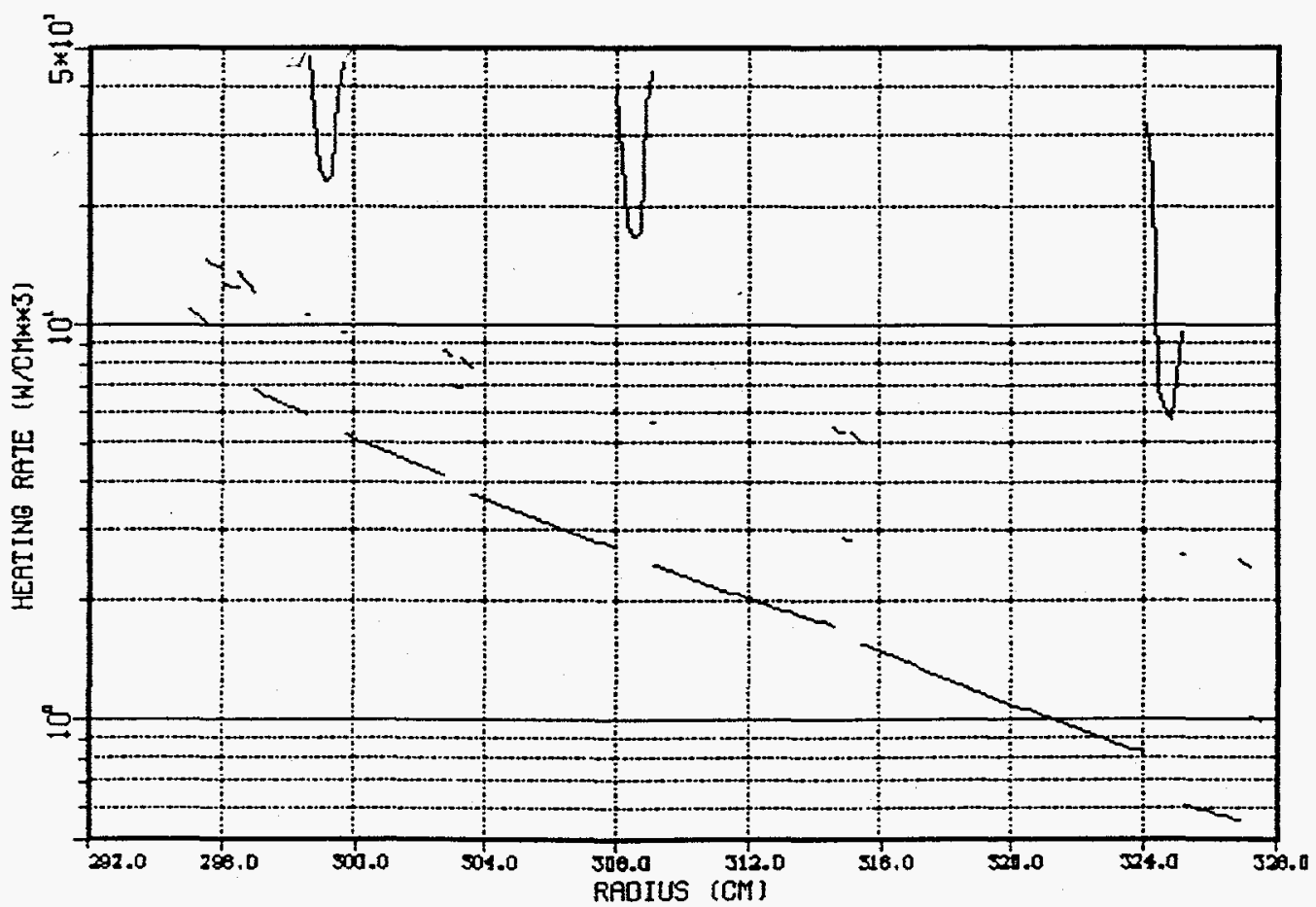

Fig. 6 Outboard Radial Distribution of the Total Nuclear Heating 


\section{TRITIUM RECOVERY AND INVENTORY}

Based on the tritium generation rate and the temperature profiles within each breeder and multiplier region, tritium inventories were calculated. Because $\mathrm{Li}_{2} \mathrm{ZrO}_{3}$ has good tritium release down to low temperatures, the calculated tritium inventories are small values. It is only $24 \mathrm{~g}$ for the total breeder inventory. Table VI gives the tritium inventory for each breeder and multiplier regions in the reactor for different neutron fluences. The calculation is based on the algorithm of [4] and net tritium breeding ratio of 0.8 .

The tritium inventory in the beryllium multiplier is considerably higher as beryllium is more tritium-retentive than $\mathrm{Li}_{2} \mathrm{ZrO}_{3}$. The algorithm for calculating tritium inventory in irradiated beryllium is based on experimental data [5]. For a porous ( $81 \%$ dense) beryllium sample irradiated at $75^{\circ} \mathrm{C}$ next to a dense sample, the tritium inventory was measured to be only $77 \%$ that of the dense sample prior to post-irradiation annealing. During annealing, the retention in the porous sample decreased from $77 \%$ to $76 \%$ after the $300^{\circ} \mathrm{C}$ anneal, to $48 \%$ after the $400^{\circ} \mathrm{C}$ anneal, to only $8.5 \%$ after the $500^{\circ} \mathrm{C}$ anneal, to $<1 \%$ after the $600^{\circ} \mathrm{C}$ anneal. As the peak beryllium temperature is $<300^{\circ} \mathrm{C}$, it is assumed that $77 \%$ of the tritium generated in the beryllium is retained as inventory. In addition, tritium decay is accounted for by assuming that it takes 10 calendar years to complete the EPP. The calculated inventories in beryllium at 1,2 , and 3 MW.a/m $\mathrm{m}^{2}$ are $0.496 \mathrm{~kg}, 0.885 \mathrm{~kg}$, and $1.247 \mathrm{~kg}$, respectively. The calculated values represent an upper limit since beryllium in ITER will be irradiated at higher temperature relative to the experimental data that will enhance the tritium release. The corresponding tritium concentrations are 4.7 appm, 8.4 appm, and 11.9 appm.

Calculations have also been performed to estimate the purge flow rate, pressure drop and pumping power. To maintain an average $\mathrm{H} / \mathrm{T}$ ratio of 10 at the purge outlet, the required helium flow rate is $1220 \mathrm{~kg} /$ day for the whole blanket. This could be accomplished with single $10-\mathrm{mm}$ diameter purge inlet/outlet tubes for each module. At atmospheric pressure, the velocity in these tubes is $-1 \mathrm{~m} / \mathrm{s}$ and both the pressure drop and the pumping power would be negligibly small. The main pressure drop would be through the breeder pebble bed. This has been calculated to be about $0.02 \mathrm{MPa}$. The pressure drop across the breeder pebble beds requires only about $4 \mathrm{~kW}$ of pumping power to maintain the desired flow rate.

\section{STRUCTURAL ANALYSIS}

It is assumed that the inboard first wall is subjected to a constant radial pressure (towards the plasma) of $1.5 \mathrm{MPa}$ during plasma centered disruptions similar to the shielding blanket. The side walls are tapered in thickness to withstand the $10 \mathrm{MPa}$ in-plane vertical pressures (up in one side wall and down in the other) acting during centered disruptions. Analyses were conducted to determine the required taper in the side walls as well as the reinforcement necessary for the first wall to withstand the $1.5 \mathrm{MPa}$ constant radial pressure.
The analysis shows that the maximum allowable pressure on the first wall without enforcement is only $\sim 1 \mathrm{MPa}$ for a 33 $\mathrm{cm}$ toroidal span. One option for reducing the bending stress in the first wall is to use stiffening ribs running toroidally at various poloidal locations. As a result, the maximum first wall bending stress, which is determined by the poloidal spacing of the beams, is reduced. However, the beams themselves are subjected to bending in the toroidal direction with a span of $0.33 \mathrm{~m}$. Fig. 6 shows the maximum allowable pressures as determined by stresses in the first wall and reinforcing beams of three sizes. At $1.5 \mathrm{MPa}$, solid beamswith a section $2 \times 4 \mathrm{~cm}$ spaced poloidally at intervals of $30 \mathrm{~cm}$ are needed to withstand the pressure during centered disruptions. An alternative option is to use reinforcing plates extending from the first wall to the back plate positioned at several poloidal locations. These plates will reinforce the first wall by direct in-plane stress rather than by bending.

Table VI

Calculated Tritium Inventories at 1,2 , and $3 \mathrm{MW} \cdot \mathrm{a} / \mathrm{m}^{2}$

\begin{tabular}{|c|c|c|c|c|c|}
\hline \multirow[t]{2}{*}{ Region } & \multirow[t]{2}{*}{ Material } & \multirow[t]{2}{*}{$\begin{array}{l}\text { Generation } \\
\text { g/day }\end{array}$} & \multicolumn{3}{|c|}{$\begin{array}{c}\text { Inventory, } \mathrm{g} \\
\text { Neutron Fluence, } \mathrm{MW} \cdot \mathrm{a} / \mathrm{m}^{2}\end{array}$} \\
\hline & & & 1 & 2 & 3 \\
\hline \multirow[t]{3}{*}{ Inboard } & $\underset{\mathrm{Li}_{2} \mathrm{ZrO}_{3}}{\mathrm{Be}}$ & 0.1509 & $\begin{array}{l}38.7 \\
3.31\end{array}$ & $\begin{array}{l}70.7 \\
3.31\end{array}$ & $\begin{array}{l}97.3 \\
3.31\end{array}$ \\
\hline & $\begin{array}{c}\mathrm{Be} \\
\mathrm{Be} \\
\mathrm{Li}_{2} \mathrm{ZrO}_{3}\end{array}$ & $\begin{array}{l}0.1526 \\
0.1135 \\
19.68\end{array}$ & $\begin{array}{l}39.1 \\
29.1 \\
5.50\end{array}$ & $\begin{array}{l}71.5 \\
51.2 \\
5.50\end{array}$ & $\begin{array}{l}78.4 \\
73.2 \\
5.50\end{array}$ \\
\hline & $\mathrm{Be}$ & 0.1357 & 34.8 & 63.6 & 87.5 \\
\hline \multirow[t]{4}{*}{ Outboard } & $\begin{array}{c}\mathrm{Be} \\
\mathrm{Li}_{2} \mathrm{ZrO}_{3}\end{array}$ & $\begin{array}{l}0.3419 \\
61.52\end{array}$ & $\begin{array}{l}87.6 \\
2.74\end{array}$ & $\begin{array}{l}160.2 \\
2.74\end{array}$ & $\begin{array}{c}220.4 \\
2.74\end{array}$ \\
\hline & $\begin{array}{l}\mathrm{Be}(0.85) \\
\mathrm{Be}(0.85) \\
\mathrm{Li} 2 \mathrm{ZO}_{3}\end{array}$ & $\begin{array}{c}0.3919 \\
0.3092 \\
52.31\end{array}$ & $\begin{array}{l}100.4 \\
79.3 \\
3.39\end{array}$ & $\begin{array}{l}183.6 \\
144.9 \\
3.39\end{array}$ & $\begin{array}{l}252.5 \\
199.4 \\
3.39\end{array}$ \\
\hline & $\begin{array}{c}\mathrm{Be} \\
\mathrm{Be} \\
\mathrm{Li}_{2} \mathrm{ZrO}_{3}\end{array}$ & $\begin{array}{c}0.1966 \\
0.1314 \\
22.36\end{array}$ & $\begin{array}{l}50.4 \\
33.7 \\
9.43\end{array}$ & $\begin{array}{l}92.1 \\
43.3 \\
9.43\end{array}$ & $\begin{array}{l}126.7 \\
84.7 \\
9.43\end{array}$ \\
\hline & $\mathrm{Be}$ & 0.0112 & 2.90 & 3.70 & 7.20 \\
\hline $\begin{array}{c}\text { Total } \\
\text { Blanket }\end{array}$ & $\begin{array}{c}\mathrm{Be} \\
\mathrm{Li}_{2} \mathrm{ZrO}_{3}\end{array}$ & $\begin{array}{c}2 \\
182\end{array}$ & $\begin{array}{c}496 \\
24\end{array}$ & $\begin{array}{l}885 \\
24\end{array}$ & $\begin{array}{c}1247 \\
24\end{array}$ \\
\hline
\end{tabular}

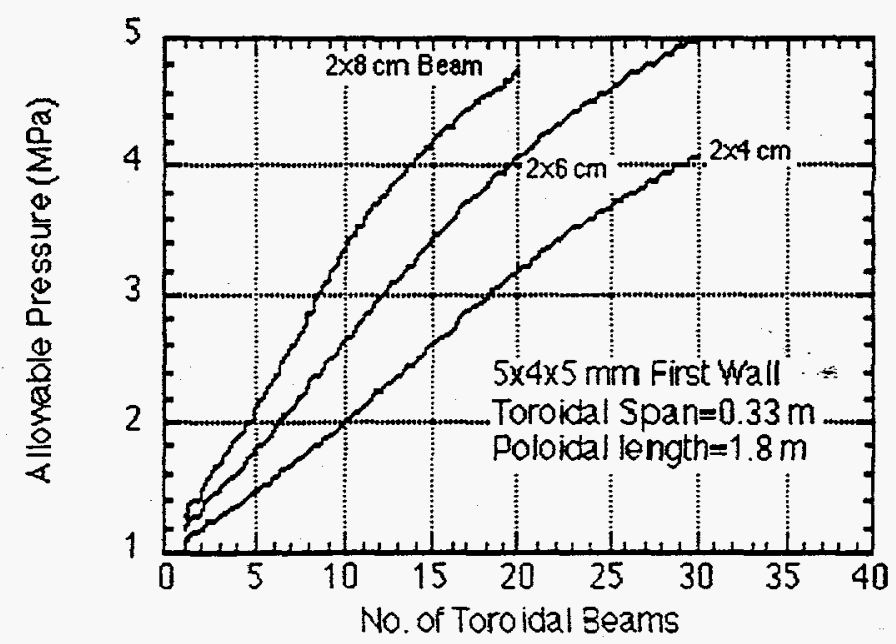

Fig. 6 Allowable pressure on inboard first wall as function of the number of toroidal stiffeners with $2 \mathrm{~cm}$ radial depth of the beams in all cases. 
Although side wall loads resulting in a zero let force on the module, the in-plane pressure acting on the site walls during eentered disruptions will have to be transmitled to the back plate as shearing forces. This will require the lickness of the side walls to be tapered from some nomind 1 value at the junction with the first wall to a larger value at the junction with the strong back. The results show for . radial blanket thickness of $22 \mathrm{~cm}$, a maximum solid thicknel s of $3 \mathrm{~cm}$ will be needed.

\section{SHIELDING ANALYSIS}

The shielding performance of the breedin blanket was checked against the design requirements as/defined in the General Design Requirement Document of th ITER project. The initial results indicate that the breeding Jlanket can be accommodated in the basic machine configura ion and satisfy the design requirements. Table VII gives the nain shielding parameters of the breeding blanket and the design margin relative to the design requirements for the Tor idal field coils and the vacuum vessel. The margin values at judged to be adequare to account for design details. nuclear da uncertainties, modeling deficiencies, radis ion transport uncertainties.

\section{DESIGN ISSUES AND RED NEIDS}

The main design issues of the breeding blanket have been identified to determine their impact on the desi|, p performance and the required $R \& D$. Design solutions, operiting ranges of the different design parameters, and $R \& D$ res its have been found to resolve some of these issues. Ceramil: beeders have demonstrated good performance in engineering tests involving

Table VII

Peak Nuclear Responses in the Toroidal Field Coils and

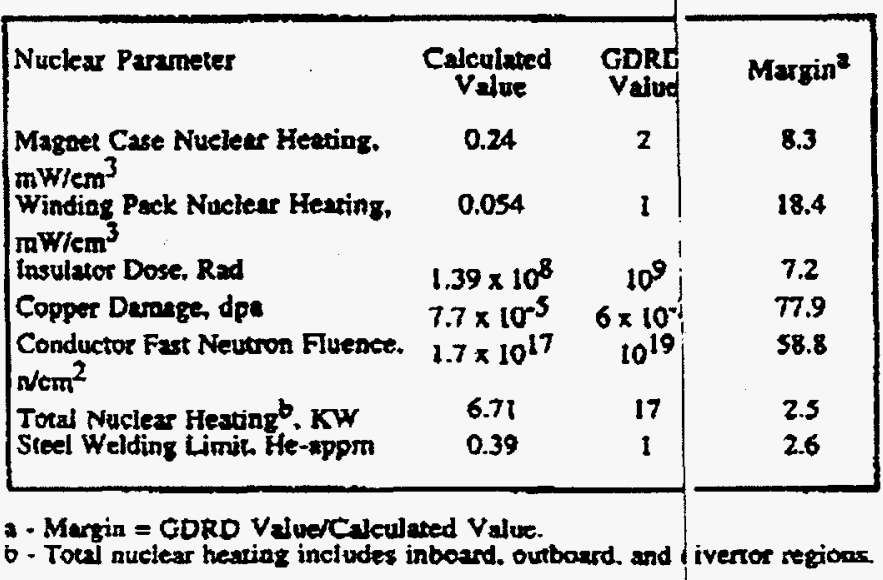

large in reactor temperature gradients (c.g., BEATRDX-II). Tritium recovery experiments from $\mathrm{Li}_{2} \mathrm{O}$ and $\mathrm{i}_{2} \mathrm{Z}_{3} \mathrm{O}_{3}$ with different operating iemperatures and heliuri purge gas conditions have confirmed low tritium inventor, and material stability. Experimental data are needed for $\mathrm{Li}_{1}: \mathrm{ZrO}_{3}$ in the $200-300^{\circ} \mathrm{C}$ temperanure range.

No feasibility issues have been found in th: use of the beryllium multiplier. There is a number of engit leering issues that need consideration to optimize the blanket performance. It is related to the fabrication method. tritium release, and swelling.

Primary issues for stainless steel stucture include radiation effects, aqueous stress corrosion. and protection against failure due to crack propagation, fatigue, or rarcheting. Based on ductility and fracture toughness measurements of inadiated material. the preferred operating temperatures for solution annealed 316 type austenitic steels are $200^{\circ} \mathrm{C}$ or $>350^{\circ} \mathrm{C}$. This low temperature range is consistent with the requirements for better aqueous stress corrosion resistance and negligible swelling. Avoid crevice conditions, minimize cyclic stresses, careful selection for the steel chemistry and fabrication procedures, maintain strict water-coolant purity, and design optimization to satisfy the structure design criteria will minimize the potential for stress corrosion cracking and steel failure.

Development of procedures for blanket module fabrication is required. An integrated thermal-hydraulic and mechanical tests should be performed to assure satisfactory performance under ITER loading conditions. Also, a small module testing in fission reactor is needed to validate tritium recovery and breeder temperature control in a neutron environment.

\section{SUMMARY}

A breeding has been developed to produce the required tritium for IIER operation during the EPP. It will also perform all the functions of the BPP shielding blanket and has the same radial build, modularity, installation, support, and replacement methods. Design issues and required R\&D data are identified during the development of the design.

\section{REFERENCES}

1. K. Ioki. A. Cardella, F. Elio, Y. Gohar, et al." "ITER Shield Blanket and Vacuum Vessel." Proceeding of 16th IEEENNPSS Symposium on Fusion Engineering. September 30-October 5, 1995.

2. D. Smith. W. Danmer, Y. Gohar, T. Kuroda, et al., "ITER Blanket, Shield and Material Data Base - Part A - ITER Blanket and Shield." International Atomic Energy Agency, Vienna. ITER Documentation Series, No. 29 (1991).

3. Y. Gohar, H. Attays. M. Billone, et al.. "U.S. Solid Breeder Blanket Design for ITER," Fusion Technology. Vol. 19, No. 3 (1991).

4. Personal Communication, March 1995.

5. M. C. Billone, W. Dienst. T. Flament, P. Lorenzetto, $\mathbf{K}$. Noda and N. Roux. "ITER Solid Breeder Blanket Materials Database." Argonne National Laboratory Report ANL/FPPITM-263. November 1993. 